\title{
Angiotensin II Receptor Binding
}

National Cancer Institute

\section{Source}

National Cancer Institute. Angiotensin II Receptor Binding. NCI Thesaurus. Code C40471.

A process that involves the non-covalent binding of angiotensin II to an angiotensin receptor family protein. These interactions are involved in signaling that modulates both blood vessel constriction and blood pressure. 